\title{
A preparative hydrophobic interaction chromatography for purification of recombinant nucleocapsid protein of Nipah virus from clarified Escherichia coli homogenate
}

\begin{abstract}
The downstream processing of the recombinant nucleocapsid $(\mathrm{N})$ protein of Nipah virus (NiV) from Escherichia coli homogenate using a preparative hydrophobic interaction chromatography (HIC) was investigated in the present study. Ammonium sulfate precipitation experiment was performed and it showed that $15 \%$ saturation of the salt was the most suitable salt concentration for the binding buffer. Batch binding of the $\mathrm{N}$ protein of NiV was performed using Sepharose ${ }^{\mathrm{TM}} 6$ Fast Flow (FF) adsorbents coupling separately with four different types of ligand; phenyl low substitution, phenyl high substitution, butyl and octyl. The phenyl low substitution ligand was selected for subsequent optimization process due to its highest yield and purity of the $\mathrm{N}$ protein achieved from the batch binding experiment. The $\mathrm{HIC}$ for purification of the $\mathrm{N}$ protein of $\mathrm{NiV}$ was further scaled-up using a $10 \mathrm{~cm}$ column packed with phenyl low substitution Sepharose ${ }^{\mathrm{TM}}$ adsorbent. A recovering yield of $81 \%$ of the $\mathrm{N}$ protein of $\mathrm{NiV}$ with a purification factor of 9.3 was achieved from this scaled-up operation. The antigenicity of the purified $\mathrm{N}$ protein was still preserved as shown in ELISA analysis.
\end{abstract}

Keyword: Hydrophobic interaction chromatography, Nucleocapsid protein, Nipah virus, Phenyl sepharose, 